\title{
MPPT VOLTAGE REGULATING IN THREE-PHASE GRID-CONNECTED PHOTOVOLTAIC SYSTEM
}

\author{
Tran Quang Tho, Truong Viet Anh \\ HCMC University of Technical Education \\ (Received November 20 $0^{\text {th }}, 2012$, Accepted January $21^{\text {st }}, 2013$ )
}

\begin{abstract}
The paper presents the method of harmonic attenuation with better dynamic response in the three-phase grid-connected photovoltaic system by using Maximum Power Point Tracking (MPPT) voltage regulator with varied increment. Since electrical power of $P V$ array depends on the climatic condition. Maximum Power Point Trackers are used to extract maximum energy from photovoltaic generators. In this paper, every time the amount of electrical power generated by solar arrays changes continuously with weather conditions, MPPT voltage is regulated quickly with large increment to decrease dynamic response time, and then with small increment to get lower current THD. The simulation results in Simulink/Matlab show that the proposed MPPT voltage regulator with varied increment is better than with fixed.
\end{abstract}

Key words: Photovoltaics (PV), maximum power point tracker (MPPT), total harmonic distortion (THD), particle swarm optimization (PSO).

\section{INTRODUCTION}

The demand of renewable energy sources such as solar energy is becoming more popular for sustainability and environment with enormous potentials [1]. In order to convert solar DC source to three-phase AC power needs to have 3-phase inverters that have been well researched in recent years [2]. Objectives of three-phase grid-connected inverters are low THD to meet grid-connected standard IEEE Std 929-2000 [3] and good dynamic response to get high efficiency [4]. Many MPPT techniques have been proposed in the literature [5], [6], [7], [8] to determine MPPT voltage. In these methods, dynamic power responses are often slow (more than $0.1 \mathrm{~s}$ ) and THD values at the output of inverter haven't been evaluated.

The Perturb and Observe (P\&O) method with constant increment in Fig. 1 is an example. If small increment is in large change irradiance condition, dynamic response time is long but output THD is lower. On the contrary, with large increment, dynamic response time is short but THD is higher. In this paper, the proposed diagram of grid-connected photovoltaic system is shown as Fig. 7. In order to generate optimal power with irradiance variety, the MPPT voltage is regulated by using $\mathrm{P} \& \mathrm{O}$ algorithm with varied increment as Fig. 5.

\section{Trang 50}




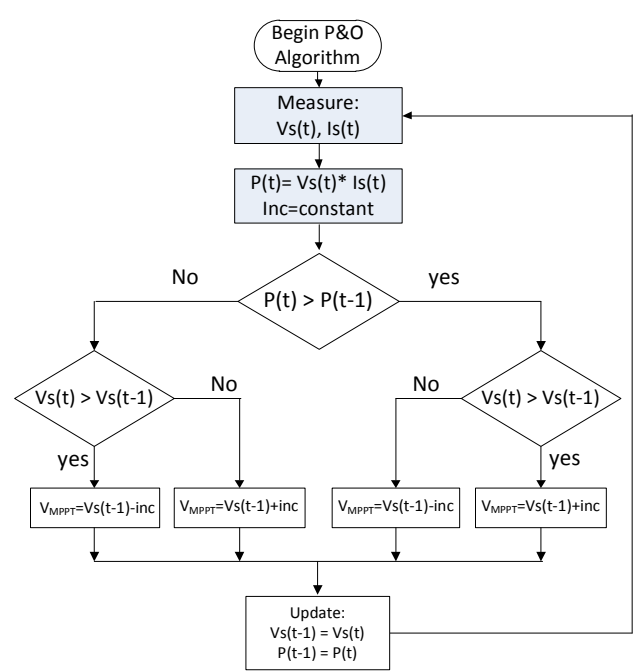

Fig 1. $\mathrm{P} \& \mathrm{O}$ algorithm with constant increment

\section{SYSTEM DESCRIPTION}

The proposed control scheme of three-phase grid-connected PV system that has been simulated includes 2 parallel rows, each row consists of $34 \mathrm{PV}$ modules (RS-P618-85W) in series connected through a DC bus to a threephase inverter that is connected to an ideal $380 \mathrm{~V}$ grid through a LCL filter. In this system, the DC link voltage is controlled accordingly to the necessary output power. The dq control structure is normally associated with PI controllers since they have a satisfactory response when regulating DC variables. Since the controlled current has to be in phase with the grid voltage, the phase angle used by the abc to dq transformation block is extracted from the grid voltage throughout the PLL.

\subsection{PV array model}

The PV array is simulated using a model of moderated complexity based on [9]. In this model, a PV cell is represented by a current source in parallel with a diode, and a series resistance as shown in Fig. 2

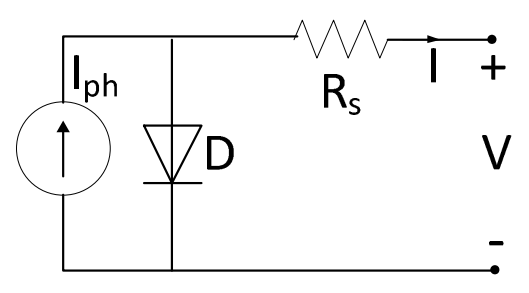

Fig. 2. The equivalent circuit model of a PV cell

The photo current $\mathrm{I}_{\mathrm{ph}}$ depends on the irradiance $\mathrm{G}$ and the cell temperature $T_{c}$. The current $I_{c}$ provided by the cell can be calculated as (1) 


$$
I_{c}=I_{p h}-I_{s}\left(e^{\frac{q\left(V+R_{s}\right)}{n K T c}}-1\right)
$$

is Boltzmann's constant and $\mathrm{T}_{\mathrm{c}}$ is cell temperature in $\mathrm{K}$.

where $I_{s}$ is the cell reverse saturation current,

$R_{s}$ is series resistance, $q$ is electronic charge, $K$

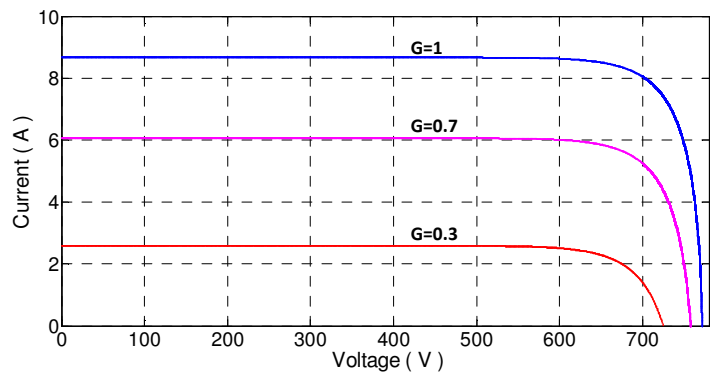

Fig. 3. PV array current vs. voltage for various irradiance and $T_{c}=298 K$

The PV array model gives a total peak power

of around $5.7 \mathrm{~kW}$. All modules are considered to be identical, and to work in identical conditions of temperature and irradiance.

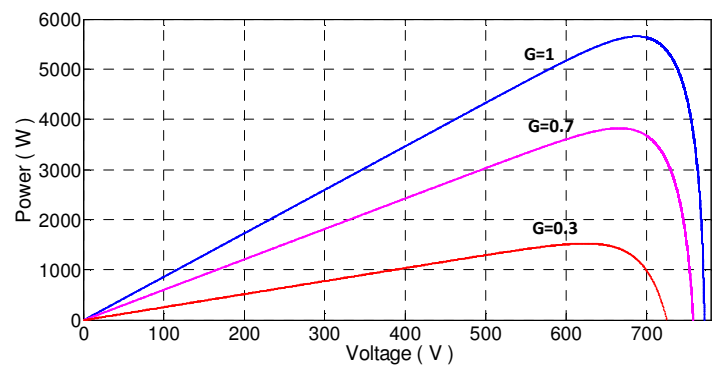

Fig. 4. $P V$ array power vs. voltage for various irradiance and $T_{c}=298 K$

\section{Trang 52}




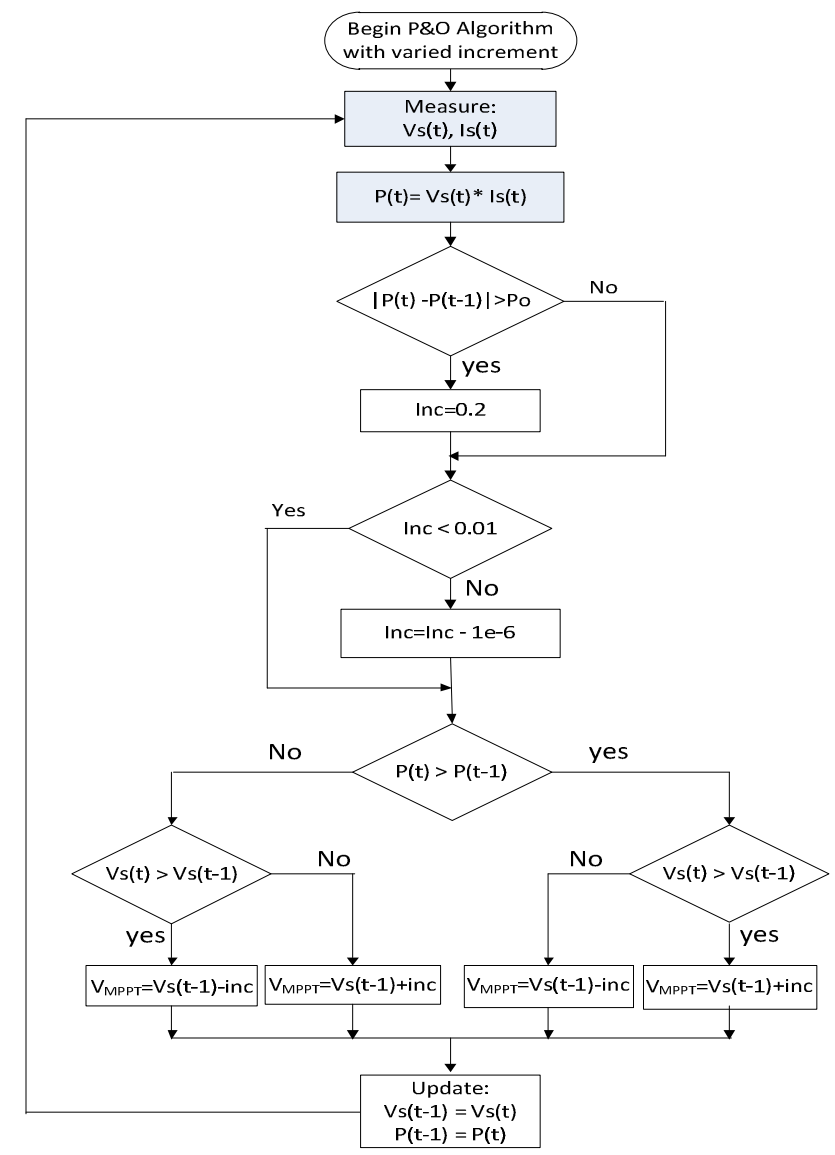

Fig. 5. The proposed MPPT flowchart

\subsection{The proposed MPPT scheme}

One of the most important objectives of any grid-connected PV converter is to extract as much power as possible from the PV array. There are various methods to perform MPPT [10], (P\&O) [11] and fuzzy logic [12] methods.

The module model with a given set of various operating conditions of irradiance and temperature shows that the relationships between voltage, current and power are charateristics similar to the ones shown in Fig. 3 and Fig. 4. MPPT voltage that corresponds to the maximum power changes with the variations of irradiance and temperature, so a MPPT system is needed to to get the max power from the module. The proposed MPPT voltage regulator is presented in this paper as shown in Fig. 5. The difference of the strategy is the varied increment that is added to $\mathrm{P} \& \mathrm{O}$ algorithm for better dynamic responds and lower current THD. The varied increment Inc is switched to high level (0.25 volt) when power changing level $|\mathrm{P}(\mathrm{t})-\mathrm{P}(\mathrm{t}-1)|$ is higher than the certain power $\mathrm{P}_{0}$ to get fast dynamic responds. After that, the Inc decreases low level (0.02 volt) to get smooth MPPT voltage 
and to have lower current THD. The d_axis reference current is also calculated in this regulator. The DC voltage of module is regulated by PI_V controller, $\mathrm{I}_{\mathrm{d}}$ and $\mathrm{I}_{\mathrm{q}}$ currents are also regulated by the PI_d and PI_q

contrllers as shown in Fig. 7. The parameters of these PI controllers are determined by PSO algorithm as table 1 .

\subsection{The inverter}

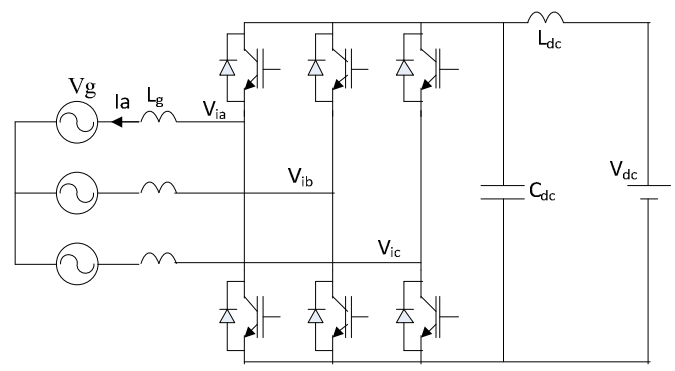

Fig 6. Simplified model of the grid-connected inverter

The system configuration of the three-phase grid-connected voltage source inverter is shown in Fig. 6. And voltage equations in synchronous reference frame are (2) and (3)

$$
\begin{aligned}
& \mathrm{V}_{\mathrm{gd}}=\mathrm{L}_{\mathrm{g}} \frac{\mathrm{di} \mathrm{d}_{\mathrm{d}}}{\mathrm{dt}}-\omega \mathrm{L}_{\mathrm{g}} \mathrm{i}_{\mathrm{q}}+\mathrm{V}_{\mathrm{id}} \\
& \mathrm{V}_{\mathrm{gq}}=\mathrm{L}_{\mathrm{g}} \frac{\mathrm{di} \mathrm{q}_{\mathrm{q}}}{\mathrm{dt}}+\omega \mathrm{L}_{\mathrm{g}} \mathrm{i}_{\mathrm{d}}+\mathrm{V}_{\mathrm{iq}}
\end{aligned}
$$

Where $V_{g d}$ and $V_{g q}$ are grid voltages respectively in dq frame. $\mathrm{i}_{\mathrm{d}}$ and $\mathrm{i}_{\mathrm{q}}, \mathrm{V}_{\mathrm{id}}$ and $\mathrm{V}_{\mathrm{iq}}$ are inverter currents and voltages respectively in dq frame. $\mathrm{L}_{\mathrm{g}}$ is inductance between inverter and grid voltage.

The output voltage of inverter is determined by the output of current regulator. In equation (2) and (3), the inverter voltage is the sum of grid voltage components and voltage drop components at the inductor $\mathrm{L}_{\mathrm{g}}$. In order to compensate the voltage deviation caused by approximate parameters and differential voltage components, PI regulator is usually used in most current regulators. Equation (2) and (3) can be represented by the equation of inverter voltage like equation (4) and (5).

$$
\begin{aligned}
& \mathrm{V}_{\mathrm{d}}^{*}=\mathrm{V}_{\mathrm{gd}}+\omega \mathrm{L}_{\mathrm{g}} \mathrm{i}_{\mathrm{q}}+\mathrm{V}_{\mathrm{cd}} \\
& \mathrm{V}_{\mathrm{q}}^{*}=\mathrm{V}_{\mathrm{gq}}-\omega \mathrm{L}_{\mathrm{g}} \mathrm{i}_{\mathrm{d}}+\mathrm{V}_{\mathrm{cq}}
\end{aligned}
$$

$\mathrm{V}^{*}{ }_{\mathrm{d}}$ and $\mathrm{V}_{\mathrm{q}}{ }_{\mathrm{q}}$ are reference voltages of inverter respectively in dq frame. $V_{c d}$ and $V_{c q}$ are the outputs of PI current regulators which can be represented in equation (6) and (7).

$$
\begin{aligned}
& \mathrm{V}_{\mathrm{cd}}=\left(\mathrm{K}_{\mathrm{p}}+\frac{\mathrm{K}_{\mathrm{i}}}{\mathrm{s}}\right)\left(\mathrm{i}_{\mathrm{d}_{-} \text {ref }}-\mathrm{i}_{\mathrm{d}}\right) \\
& \mathrm{V}_{\mathrm{cq}}=\left(\mathrm{K}_{\mathrm{p}}+\frac{\mathrm{K}_{\mathrm{i}}}{\mathrm{s}}\right)\left(\mathrm{i}_{\mathrm{q}_{-} \text {ref }}-\mathrm{i}_{\mathrm{q}}\right)
\end{aligned}
$$

Where $i_{d_{\_} \text {ref }}$ and $i_{q_{-} \text {ref }}$ are reference currents of inverter respectively in $\mathrm{dq}$ frame. For power factor is unity, $\mathrm{i}_{\mathrm{q}_{-} \text {ref }}=0$.

\section{Trang 54}




\section{SIMULATION RESULTS}

\subsection{Simulation parameters}

The system scheme shown as Fig .7 has been simulated on Matlab/Simulink and Table 1 is the summary of the system parameter values.

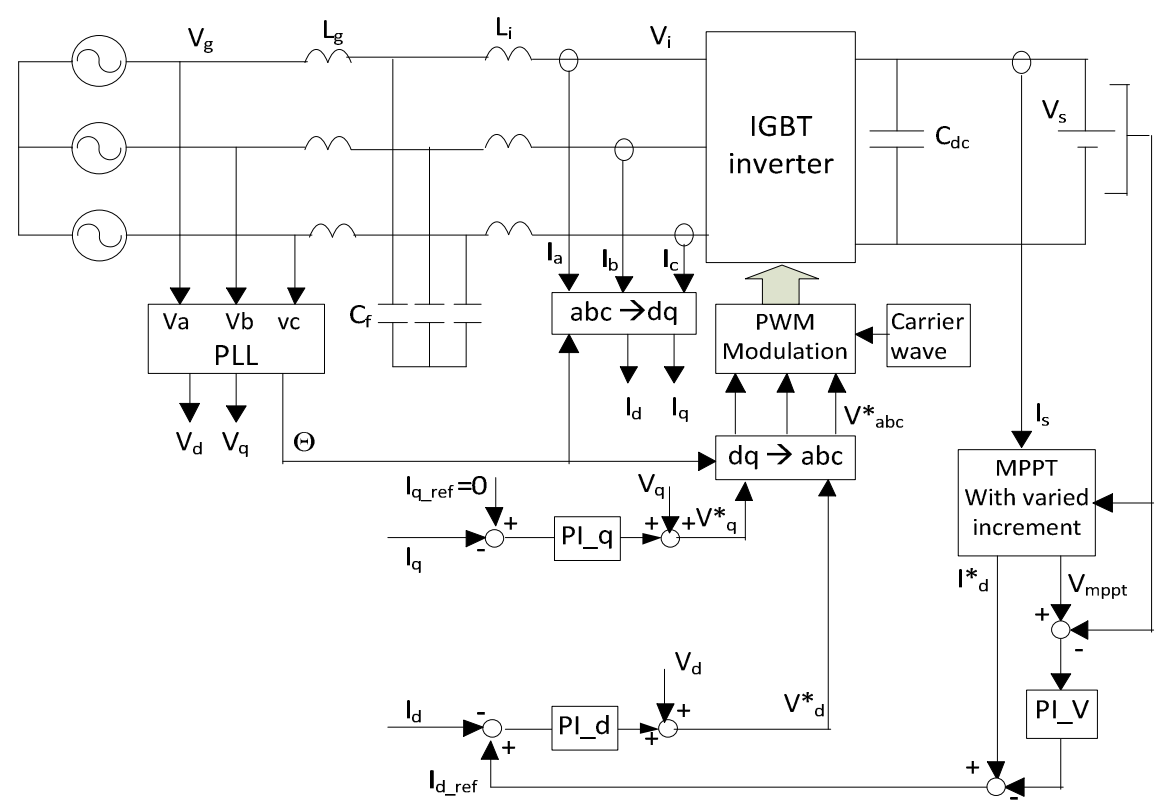

Fig. 7. General diagram of grid-connected photovoltaic system

Table 1. the system parameters

\begin{tabular}{|l|l|l|}
\hline Parameter & Description & Value \\
\hline $\mathrm{L}_{\mathrm{g}}$ & Grid inductance & $0.5 \mathrm{mH}$ \\
\hline $\mathrm{R}_{\mathrm{g}}$ & Resistance of $\mathrm{L}_{\mathrm{g}}$ & $0.01 \Omega$ \\
\hline $\mathrm{L}_{\mathrm{i}}$ & Inverter inductance & $1.8 \mathrm{mH}$ \\
\hline $\mathrm{R}_{\mathrm{i}}$ & Resistance of $\mathrm{L}_{\mathrm{i}}$ & $0.1 \Omega$ \\
\hline $\mathrm{C}_{\mathrm{f}}$ & Filter capacitor & $10 \mu \mathrm{F}$ \\
\hline $\mathrm{F}_{\mathrm{PWM}}$ & PWM frequency & $9 \mathrm{kHz}$ \\
\hline $\mathrm{F}$ & Grid frequency & $50 \mathrm{~Hz}$ \\
\hline $\mathrm{S}_{\mathrm{b}}$ & Base power & $40 \mathrm{KVA}$ \\
\hline $\mathrm{V}_{\mathrm{b}}$ & Base voltage & $380 \mathrm{~V}$ \\
\hline $\mathrm{K}_{\mathrm{p} \_\mathrm{dq}}$ & $\mathrm{K}_{\mathrm{p}}$ of PI_d and PI_q & 393 \\
\hline $\mathrm{K}_{\mathrm{i} \_\mathrm{dq}}$ & $\mathrm{K}_{\mathrm{i}}$ of PI_d and PI_q & 397 \\
\hline $\mathrm{K}_{\mathrm{p}_{-} \mathrm{v}}$ & $\mathrm{K}_{\mathrm{p}}$ of PI_V & 6 \\
\hline $\mathrm{K}_{\mathrm{i}_{\_} \mathrm{v}}$ & $\mathrm{K}_{\mathrm{i}}$ of PI_V & 0.005 \\
\hline $\mathrm{C}_{\mathrm{dc}}$ & DC bus capacitor & $1500 \mu \mathrm{F}$ \\
\hline
\end{tabular}




\subsection{MPPT with fixed increment $=0.25 \mathrm{~V}$}

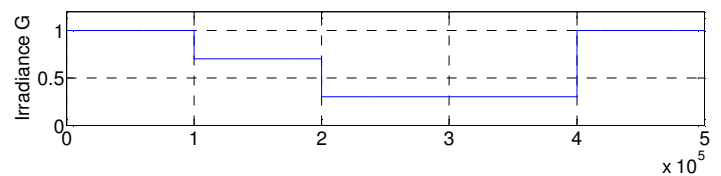

Fig. 8. Irradiance change and large fixed increment ( 0.25 volt $)$
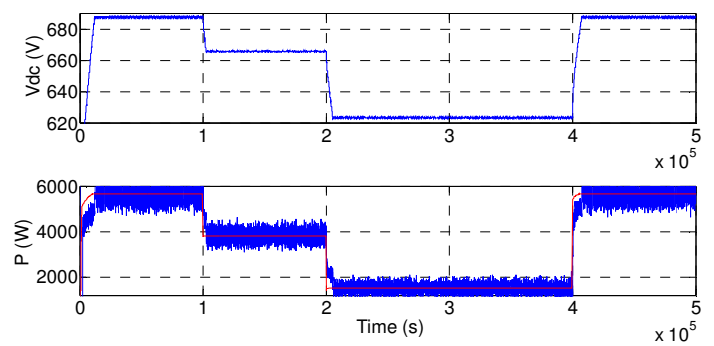

Fig. 9. $P V$ array $V_{d c}$ and power responses with large fixed increment
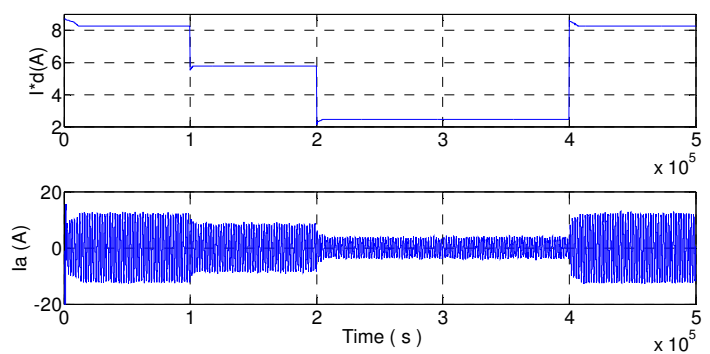

Fig .10. Grid current and $I^{*}{ }_{d}$ with large fixed increment

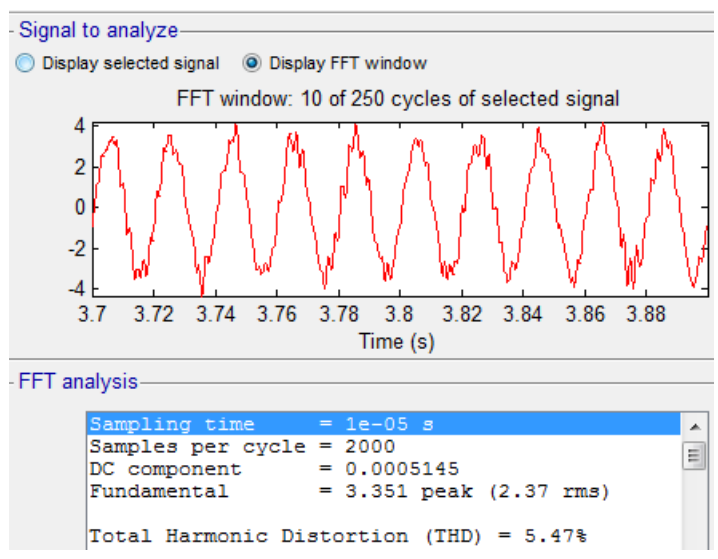

Fig. 11. The phase current THD

\section{Trang 56}


The simulation results in Fig. 8 to Fig. 11 show that dynamic responses of PV array power are very fast but current THD is higher than $5 \%$.

\subsection{MPPT with fixed increment $=0.02 \mathrm{~V}$}

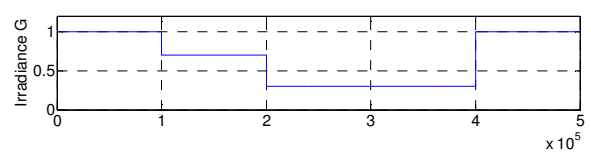

Fig. 12. Irradiance change and small fixed increment (0.02 volt)

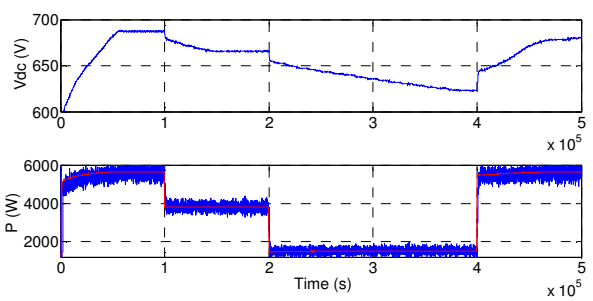

Fig .13. PV array $V_{d c}$ and power responses with small fixed increment
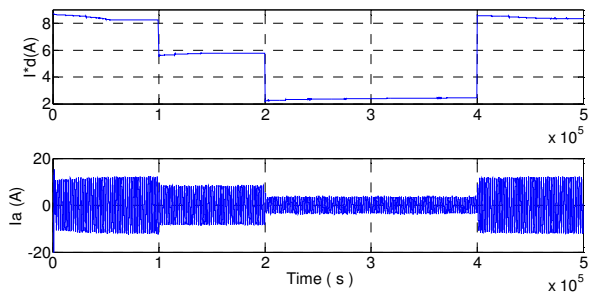

Fig. 14. Grid current and $I^{*}{ }_{d}$ with small fixed increment

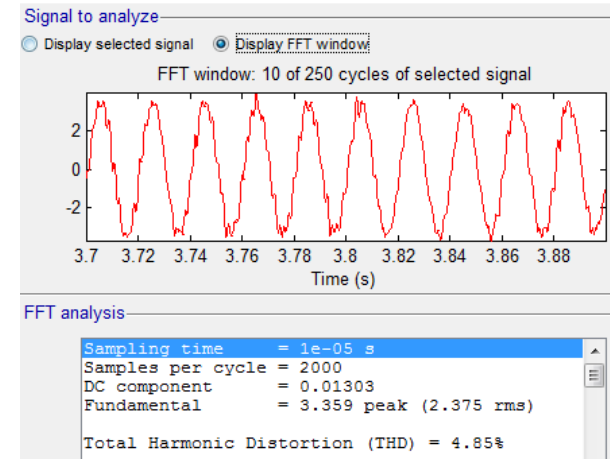

Fig. 15. The phase current THD

The simulation results in Fig. 12 to Fig. 15 power are very slowly but current THD is show that dynamic responses of PV array lower than $5 \%$. 


\subsection{MPPT with varied increment}
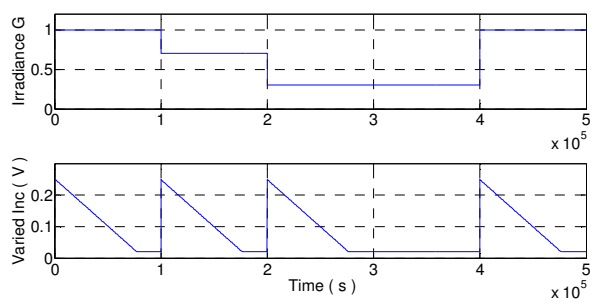

Fig. 16. Irradiance change and varied increment ( 0.02 to 0.25 volt)

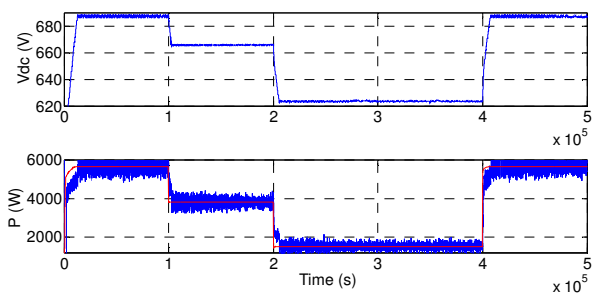

Fig. 17. $P V$ array $V_{d c}$ and power responses with varied increment
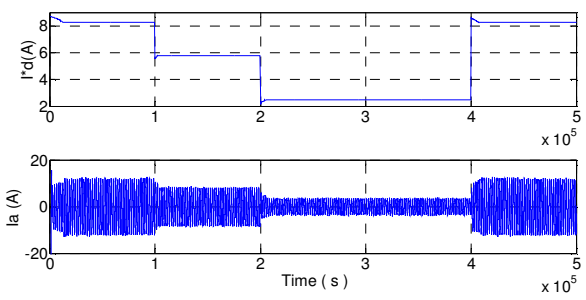

Fig. 18. Grid current and $I^{*}{ }_{d}$ with varied increment

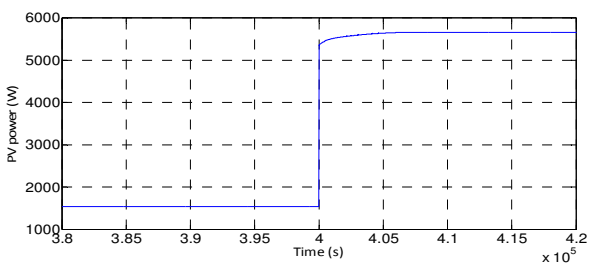

Fig. 19. System $P V$ power response to an irradiance step at $t=4 \mathrm{~s}$

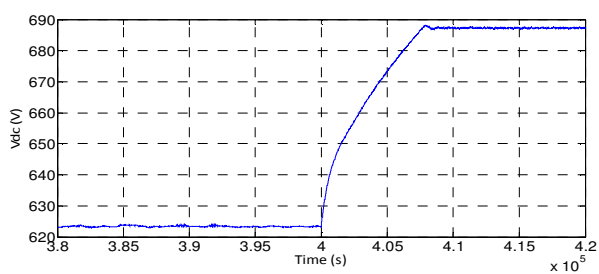

Fig. 20. System $V_{d c}$ response to an irradiance step at $t=4 s$

\section{Trang 58}




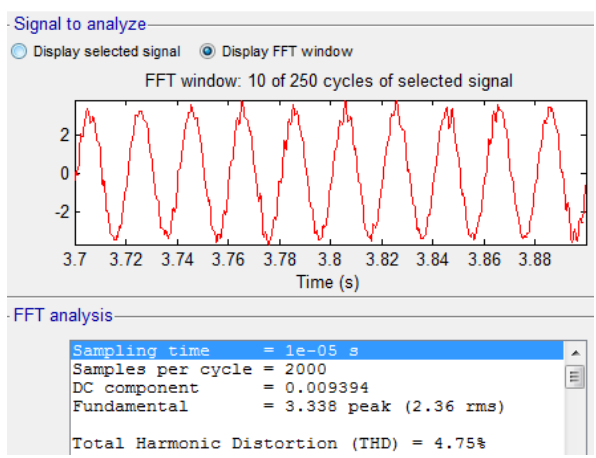

Fig. 21. Phase current THD

The system responses to an irradiance step is shown in Fig. 16 to Fig. 20 at $t=4 s$ when the irradiance is changed from $300 \mathrm{~W} / \mathrm{m}^{2}$ to $1000 \mathrm{~W} / \mathrm{m}^{2}$. They show that the system tracks the maximum operating point faster than most MPPT strategies. Irradiation change level is very extremely rapid that shows the good performance of the proposed MPPT voltage regulator.

\section{CONCLUSIONS}

A three-phase grid-connected photovoltaic inverter system has been presented. In this paper, the inverter does not require an intermediate stage of DC/DC control to get optimal power. In order to extract the maximum power from the PV module, a MPPT voltage regulator is applied by using $\mathrm{P} \& \mathrm{O}$ algorithm with varied increment to get better dynamic responds and lower current THD. The simulation results in Simulink/Matlab show that the proposed MPPT voltage regulator with varied increment is better than with fixed. 


\title{
ĐIỀU CHỈNH ĐIỆN ÁP MPPT TRONG Hệ THỐNG ĐIỆN MặT TRỜI NỐI LƯỚI 3 PHA
}

\author{
Trần Quang Thọ, Trương Việt Anh
}

Trường Đại học Sư phạm Kỹ thuât Tp.HCM

TÓM TÁT: Bài báo này trình bày phuoong pháp giảm thiểu sóng hài trong hệ thống pin mặt trời nối lưới 3 pha với đáp ứng động nhanh bằng cách sư dụng bộ điều chỉnh điện áp MPPT có gia số biến thiên. Do công suất điện của dàn pin mặt trời thay đổi theo điều kiện thời tiết. Bộ dò điểm công suất cực đại MPPT được sủ̉ dụng để chiết xuất năng luợng điện cưc đại của dàn pin. Trong bài báo này, mỗi khi công suất điện của dàn pin thay đổi theo điều kiện thời tiết, điện áp MPPT sẽ đuợc chinh rất nhanh đến điểm có công suất cực đại với gia số lớn, sau đó gia số sẽ giảm nhỏ xuống để nhằm đạt được độ méo dạng sóng hài THD dòng điện thấp hơn. Kết quả mô phỏng trên Simulink/Matlab cho thấy bộ điều chinh điện áp MPPT đề xuất có gia số biến thiên tốt hơn bộ điều chỉnh có gia số cố định.

Tù khóa: Pin mặt trời (PV), bộ dò điểm công suất cực đại (MPPT), độ méo dạng sóng hài toàn phần (THD), tối uu bầy đàn (PSO).

\section{REFERENCES}

[1]. Stéphan Astier, Systèmes solaires photovoltaïques, Seminar on 15/02/2011 at Technical University HCM city.

[2]. Amirnaser Yazdani and Prajna Paramita Dash, A Control Methodology and Characterization of Dynamics for a Photovoltaic (PV) System Interfaced With a Distribution Network, IEEE Transactions on Power Delivery, Vol. 24, No. 3, July (2009).

[3]. IEEE Recommended Practice for Utility Interface of Photovoltaic (PV) systems, IEEE Standard 929-2000, Jan. (2000).

[4]. C. R. Sullivan and M. J. Powers, A highefficiency maximum power point tracker for photovoltaic array in a solar- powered race vehicle, in Proc. IEEE PESC, (1993).

[5]. Yun Tiam Tan, Daniel S. Kirschen, Nicholas Jenkins, A Model of $P V$ Generation Suitable for Stability Analysis, in IEEE Transactions on Energy Conversion, vol. 19, no. 4, December (2004).

[6]. N. Patcharaprakiti and S. Premrudeepreechacharn, Maximum power point tracking using adaptive fuzzy logic control for grid-connected photovoltaic system, in IEEE Power Engineering Winter Meeting, (2002).

[7]. D. Shmilovitz, On the control of photovoltaic maximum power point tracker via output parameters, IEE

\section{Trang 60}


Proc.-Electr. Power Appl., Vol. 152, No. 2, March (2005).

[8]. B. Nagaraju, A Fuzzy Logic MPPT Three-Phase Grid-Connected Inverter for Photovoltaic Applications, IJERA Vol. 2, Issue 1, 104-107, Jan-Feb (2012).

[9]. Huan-Liang Tsai, Insolation-oriented model of photovoltaic module using Matlab/Simulink,

www.sciencedirect.com, Solar Energy 84, 1318-1326, (2010).

[10].W. Libo, Z. Zhengming, and L. Jianzheng, A single-stage three-phase grid-connected photovoltaic system with modified MPPT method and reactive power compensation, IEEE Trans. Energy Convers., vol. 22, no. 4, 881886, Dec. (2007)

[11]. H. Yongji and L. Deheng, A new method for optimal output of a solar cell array, in Proc. IEEE Int. Symp. Industrial Electronics, vol.1, 456-459, (1992).

[12]. Ahmed G. Abo-Khalil, Dong-Choon Lee, Jong-Woo Choi, and Heung-Geun Kim, Maximum Power Point Tracking Controller Connecting PV System to Grid, Journal of Power Electronics, Vol. 6, No. 3, , 226-234, July (2006). 